\title{
Pedagoško-psihološki elementi prehoda $v$ visokošolsko izobraževanje
}

\author{
Sonja Rutar \\ Univerza na Primorskem \\ sonja.rutar@pef.upr.si \\ Sonja Čotar Konrad \\ Univerza na Primorskem \\ sonja.cotarkonrad@pef.upr.si
}

Prispevek obravnava prehode med različnimi stopnjami izobraževanja, s poudarkom na prehodu v visokošolsko izobraževanje. Preučevali smo, kako so študentje dodiplomskih študijskih programov Pedagoške fakultete Univerze na Primorskem doživljali prehode na različnih stopnjah izobraževanja, kako se kaže kontinuiteta čustvenega in socialnega doživljanja med stopnjami izobraževanja ter kako se čustveno-socialne izkušnje doživljanja prehoda na fakulteto povezujejo s pedagoškoprocesnimi elementi študijskega procesa. Ugotavljamo, da se prijetnejše počutje posameznika v novem okolju, večja socialna vključenost in način spoprijemanja s stresom na prehodu pomembno povezujejo s pedagoškoprocesnimi elementi študijskega procesa. Prehod v visokošolsko okolje v primerjavi z drugimi stopnjami izobraževanja pomeni najzahtevnejši prehod med izobraževalnimi stopnjami. To pa potrjuje potrebo po načrtnem organiziranju procesov in aktivnosti $v$ podporo študentom pri prehajanju na visokošolsko raven izobraževanja.

Ključne besede: prehod, izobraževalne stopnje, spoprijemanje z obremenitvami, osebnost, pedagoškoprocesni elementi, visokošolsko izobraževanje

\section{Uvod}

Da prehod med enim in drugim izobraževalnim obdobjem ali enim in drugim okoljem postane viden ter obravnavan, je treba biti pozoren na počutje in občutja posameznika, ki doživlja prehod. Prehodi niso formalno umeščeni $v$ nobeno vzgojno-izobraževalno obdobje, pa vendar obstajajo. Zato se vedno bolj zavedamo, da se posameznik, ki vstopa v različna okolja in na različne stopnje izobraževanja, ob vsakem soočanju z novo situacijo in okoljem sooča tudi z izzivi prehodov. Aktualna pozornost pri obravnavi mnogoterih prehodov je $v$ veliki meri povezana tudi s skrbjo za posameznika in skupine $z$ določenimi značilnostmi (ranljive skupine), pogosto razvojno specifičnimi in kulturno-jezikovnimi, kar izhaja iz spoznanj o vplivih okolja na posameznikove priložnosti in možnosti za razvoj ter učenje (Bronfenbrenner 1979). 
Pred tem je bil na prehodih iz enega $v$ drugo izobraževalno obdobje poudarek predvsem na pripravljenosti posameznika za vstop v drugo izobraževalno stopnjo (Arnold idr. 2007). Ravno pripravljenost za učenje v naslednji izobraževalni stopnji je bila najpogosteje predmet obravnav, ki so se povezovale z učinkovitostjo sistemov $v$ funkciji pripravljanja posameznika na kasnejšo učno uspešnost (Winter in Kelley 2008). Občutja in doživljanja posameznika ter razlogi za ta doživljanja so bili v tej perspektivi pogosto spregledani. Sodoben način pojmovanja prehodov v izobraževanju presega razumevanje, da je uspeh odvisen zgolj od posameznikove zrelosti, pripravljenosti, pač pa pozornost in prizadevanja usmerja tudi v zagotavljanje pripravljenosti in ustreznosti sistema za posameznika (Woodhead in Moss 2007). Ta namreč vstopa v novo okolje, ki naj bi izkazovalo pripravljenost za sprejemanje novinca in prilagajanje posamezniku, omogočanje njegovega dobrega počutja ter participativne realizacije njegovih potencialov.

Problem diskurzov in obravnave prehodov ilustrativno predstavi Downes (2019), ki meni, da je pri prehodu otrok pogosto obravnavan kot »riba, ki je v novem kontekstu brez vode«, namesto da bi večjo pozornost namenili vprašanju, ali je okolje reke onesnaženo, tj. za novince neustrezno, torej kako in koliko se mora ob sprejemanju novincev šolski sistem prilagoditi, spremeniti (str. 1467). Downes $(2019,1467)$ pravi: „Če riba plava v onesnaženi reki, ni težava s samim prehodom, pač pa z onesnaženostjo - zato je treba spremeniti reko kot okolje sistema, in ne pričakovati, da se bo riba prilagodila onesnaženi reki.»

V perspektivi, ki zagovarja potrebo po zagotavljanju ustreznega sistema in okolja za posameznika, sta pomembna posameznik in njegovo doživljanje sistema. Način doživljanja prehodov namreč ne vpliva zgolj na prve mesece posameznikovega vključevanja v novo okolje, pač pa ima na delovanje posameznika dolgotrajnejši vpliv, kajti njegovo doživljanje uspešnosti v novem okolju vpliva na njegove kasnejše izkušnje (Dunlop in Fabian 2006, 2). Zato nas je v raziskavi zanimalo, kako so študentje dodiplomskih študijskih programov Pedagoške fakultete Univerze na Primorskem doživljali prehode na različnih stopnjah izobraževanja ter kako se čustveno-socialno doživljanje prehoda na fakulteto povezuje s pedagoškoprocesnimi elementi študijskega procesa. Ugotoviti smo želeli tudi pojav morebitne kontinuitete čustvenega in socialnega doživljanja med različnimi stopnjami izobraževanja, natančneje, ali obstaja povezanost med čustvenim in socialnim doživljanjem od vključevanja v vrtec do vstopa v osnovno šolo, srednjo šolo in nenazadnje na fakulteto. Preverjali smo tudi doživljanje prehodov v povezavi z osebnostnimi značilnostmi in $\mathrm{s}$ spoprijemanjem $\mathrm{s}$ stresom ob prehodu ter pedago- 
škoprocesnimi elementi učnega/študijskega procesa na posamezni stopnji izobraževanja.

\section{Prehodi na različnih stopnjah izobraževanja}

Za vse prehode je značilno vstopanje posameznika v novo, pogosto neznano okolje, ki načeloma za vsakega pomeni bolj ali manj izrazit stres, s katerim se je potrebno soočiti. Ker pa se od posameznika vseeno pričakuje, da bo na novi izobraževalni stopnji uspešno deloval, je na eni strani način soočanja $z$ obremenitvami in spoprijemanja s stresom gotovo pomemben element uspešnega prilagajanja na novo izobraževalno okolje. Po drugi strani pa je dosežen konsenz, da je za uspešen prehod učečih se v določena izobraževalna okolja treba zagotoviti ustrezne pogoje. Tako je študija OECD (2017) za mehek prehod $v$ šole izpostavila profesionalno, strokovno in razvojno kontinuiteto. Gre za sintezo sistemskih in procesnih vidikov - ustrezne in primerljive izobrazbe strokovnih delavcev, kurikuluma, pedagoških pristopov in upoštevanja razvojnih značilnosti učečih se - z namenom zagotavljanja dobrega počutja in ustrezne vključenosti posameznika - tistega, ki vstopa in prehaja v sistem. Šele znotraj sistemske organiziranosti ima posameznik možnost, in to na vseh stopnjah izobraževanja, da doživi uspeh, kar ni več odvisno zgolj od njegovih dotakratnih izkušenj in razvitih sposobnosti ter njegovega predhodnega mikrosistema (Bronfenbrenner 1979), pač pa tudi od sistemsko zagotovljenega strokovno ustreznega in podpornega okolja.

Ob nujnosti zagotavljanja mehkih prehodov v izobraževanju (OECD 2017) pa je treba poudariti, da na razumevanje vloge otroka in mladostnika v izobraževanju zagotovo vpliva tudi predstava, podoba o otroku, mladostniku oz. učečemu se (Malaguzzi 1994). Razumevanje vloge slednjega namreč predstavlja izhodišče sistemske organizacije izobraževanja ter pedagoškega ravnanja na vseh stopnjah izobraževanja. Tako se posameznik $v$ fazi prehodov pogosto znajde $v$ procesu, ki ga zgolj doživi, dejansko pa v negotovosti in z nepoznavanjem novega stanja lahko postane nehote ujet v prikrita pričakovanja in prikrite družbene kurikulume ter strukture (Alsubaie 2015).

Najpogosteje je bil v preteklosti, tudi v slovenskem okolju, obravnavan prehod iz vrtca v šolo (Vonta 1993), aktualno pa je zanimanje za prehod iz družinskega v vrtčevsko okolje s perspektive staršev oz. družin in otrok (Markström in Simonsson 2017). Obema prehodoma je že kurikularna prenova v Sloveniji leta 1996 namenila strokovno in sistemsko skrb (Ministry of Education, Science and Sport in National Educational Institute Slovenia 2017). $Z$ namenom zagotavljanja pedagoške in razvojne kontinuitete $v$ prvem razredu osnovnih šol poučujeta učitelj razrednega pouka in vzgojitelj predšol- 
skih otrok (Zakon o osnovni šoli 2006), vrtci pa zagotavljajo prehod iz doma v vrtec s postopnim uvajanjem otrok vanj, kar je staršem in otrokom, skladno s kurikularnimi načeli sodelovanja s starši, tudi omogočeno (Ministrstvo za šolstvo in šport 1999). Za ustrezno, predvsem karierno, podporo pri prehodih učencev iz osnovnih $v$ srednje šole pa so $v$ skladu s svojimi nalogami zadolžene svetovalne službe osnovnih (Resman 2008) in srednjih šol (Zavod Republike Slovenije za šolstvo 2008). Programske smernice za srednje šole opredeljujejo delo svetovalne službe tudi v funkciji »spremljanja in svetovanja novincem, ponavljalcem, preusmerjenim [...], gre za probleme prehoda in prilagajanja, učno, vedenjsko, socialno in osebnostno problematiko« (str. 21).

Visokošolsko izobraževanje je v zadnjem desetletju pri prehodih na to stopnjo zagotovilo predvsem podporo kariernih centrov, vpisnih služb, referatov, tutorjev učiteljev in študentov. Tutorski sistem se je na Univerzi na Primorskem začel razvijati z zavedanjem, da študentje potrebujejo podporo pri vključevanju v nova okolja (Univerza na Primorskem 2016). Pojmovanje tutorstva na visokošolski ravni tako presega nalaganje individualne odgovornosti za uspeh izključno študentom, kar kaže na povezovanje akademske uspešnosti s pedagoško podporo (Vygotsky 1978), socio-kulturnimi značilnostmi ter z ekološkimi pogoji za učenje in razvoj posameznikov (Bronfenbrenner 1979). S tem se presega klasično pojmovanje individualne odgovornosti in pripravljenosti posameznika za vstop v določena izobraževalna okolja in posledično za kasnejšo študijsko uspešnost.

Čeprav je bil prehod na univerzitetno raven doslej manj pogosto obravnavan, je eden izmed ključnih razlogov za nujnost aktualne obravnave tudi dejstvo, da se je delež študentov (Calderon 2018), ki vstopajo v visokošolsko okolje, povečal. Nedvoumno je, da prehod v visokošolsko izobraževanje zahteva zmožnost študentov za prilagajanje, sočasno pa je pomembna pomoč visokošolskega prostora, da študentje te spremembe zmorejo (Liddle 2016). S tem pridobijo občutek namena visokošolskega izobraževanja, kar vključuje jasno razumevanje vsebine, načina učenja in poučevanja ter povezovanja $s$ svojimi vrstniki v univerzitetni skupnosti Liddle 2016). S tem pa se tudi vzpostavijo pogoji za dobro počutje in mentalno zdravje študentov (Baik, Larcombe in Brooker 2019).

Akademsko prilagajanje je ob vstopu študentov v univerzitetno okolje najzahtevnejše in najobčutljivejše prav na začetku študija (Abdullah idr. 2009; Enochs in Roland 2006; Wintre in Yaffe 2000). V prvih mesecih po vstopu $v$ univerzitetno okolje morajo namreč skozi proces čustvenega doživljanja in aktivnega prilagajanja na nove, študijske zahteve (Gadzella in Carvalho 2006), kot so spoznavanje in razumevanje načina izvedbe študijskega pro- 
cesa, organizacija lastnega študija, morebitno prilagajanje na nove bivanjske razmere, oblikovanje novih socialnih mrež itd. Upoštevajoč omenjene značilnosti lahko prehajanje med izobraževalnimi stopnjami, natančneje prehod na fakulteto, opredelimo kot stresno situacijo, ki od vsakega posameznika zahteva njemu lasten, bolj ali manj uspešen odziv. $V$ okviru tega so mladi na prehodu v odraslost postavljeni pred vprašanji (i) premisleka o lastnem načinu poprijemanja $s$ stresom in soočanja $z$ novimi obremenitvami ter (ii) razumevanja sebi lastnega čustvenega, socialnega in pedagoškega vidika doživljanja prehoda na novo stopnjo izobraževanja. Študije namreč kažejo (npr. McCloskey 2011), da študenti glede na osebnostne značilnosti soočanja $z$ obremenitvami in procesne vidike študijskega procesa že $v$ začetnem študijskem obdobju izoblikujejo študijske navade in rutine, ki se kasneje kažejo kot stalni način pristopanja k opravljanju študijskih obveznosti in pomembno vplivajo na njihove akademske dosežke (Abdullah idr. 2009).

Uspešnost doseganja učnih izidov in posledično tudi akademskih dosežkov pa se gotovo ne dotika zgolj študenta samega, ampak tudi (i) kolegov, s katerimi študent sodeluje (Steel in Ferrari 2013), (ii) visokošolskih učiteljev, ki pričakujejo pravočasno in ustrezno opravljene študijskih obveznosti, ter nenazadnje tudi (iii) fakultete in univerze. $V$ okviru tega je posameznikovo doživljanje na prehodu med stopnjami izobraževanja tema, ki jo je smiselno in pomembno nasloviti. Ob tem menimo, da so lahko dejavniki, ki lahko olajšajo ali otežijo prehajanje med izobraževalnimi stopnjami, individualni in institucionalni (strukturni in procesni). Če torej prvi izhajajo iz narave vsakega posameznika (npr. osebnostne značilnosti in strategije spoprijemanja s stresom), pa drugi zajemajo značilnosti okolja, v katerega posameznik vstopa (npr. značilnosti učnega okolja in strukturiranosti sistema, delovanje učitelja, informiranost oz. dostopnost informacij itd.).

Izhajajoč iz predpostavke, da prehod med izobraževalnimi stopnjami pomeni stresor, ki v posamezniku sproža stresni odziv, na katerega se v skladu s svojimi osebnostnimi značilnostmi in podporo okolja odziva na različne načine, bomo v nadaljevanju prispevka opredelili model osebnosti velikih pet ter strategije spoprijemanja s stresom, ki lahko pomembno sodoločajo uspešnost posameznikovega prehoda med izobraževalnimi stopnjami.

\section{Osebnost in spoprijemanje $s$ stresom prehoda}

Osebnost lahko opredelimo kot kompleksen vzorec spoznavnih, čustvenih in vedenjskih značilnosti delovanja posameznika (Connor-Smith in Flachsbart 2007). Model velikih pet osebnostnih dimenzij je najpogostejši model razlage osebnosti, za katerega velja, da z empiričnim in s teoretičnim raziskovalnim 
soglasjem lahko utemeljujemo izvor dimenzij osebnosti na osnovi bioloških struktur ter procesov (McCrae idr. 2000). Model opisuje osebnost na osnovi naslednjih petih dimenzij (McCrae idr. 2000):

- ekstravertnost (E; angl. extraversion): značilne so pogostejša prisotnost pozitivnih čustev, sociabilnost, asertivnost, visoka stopnja aktivnosti in občutljivost na nagrade, torej odzive socialnega okolja na vedenje posameznika;

- nevroticizem ( $\mathrm{N}$; angl. neuroticism): pogostejša prisotnost negativnih čustev in čustvene nestabilnosti, večje samozavedanje, intezivnejša čustvena in fiziološka odzivnost na stresorje ter inhibicija vedenja;

- sprejemljivost (S; angl. agreeableness): altruistično vedenje, zaupanje, težnja po medsebojni usklajenosti, harmoničnosti in naklonjenosti;

- vestnost (V; angl. conscientiousness): značilna je visoka stopnja samoregulacije posameznika, vztrajnosti, nadzora impulzov, orientacije k dosežku in samodisciplini;

- odprtost za izkušnje ( $\mathrm{O}$; angl. openness to experience): pomeni težnjo $\mathrm{k}$ ustvarjalnosti, radovednosti, fleksibilnosti, rabi domišljije in vpletenosti posameznika $v$ velik nabor intelektualnih izzivov.

Raziskave (npr. Hendriks idr. 2003) kažejo, da so omenjene dimenzije stabilne ne glede na starostno obdobje kot tudi sociokulturno ozadje posameznika. Iz tega lahko sklepamo, da model velikih pet pomeni pomembno izhodišče razumevanja vplivanja osebnosti tudi na načine spoprijemanja s stresom pri prehajanju med izobraževalnimi stopnjami.

Čeprav večina raziskovalcev danes jasno ločuje med osebnostjo (angl. personality) in spoprijemanjem s stresom ( $v$ nadaljevanju: spoprijemanje; angl. coping), so nekatere opredelitve spoprijemanja relativno široke: avtorji ga definirajo kot osebnostno potezo posameznika, torej kot »specifičen, zanj značilen način odzivanja na kakršno koli spremembo v okolju« (Beutler, Moos in Lane 2003, 1158). V okviru tega je spoprijemanje razumljeno kot nehotni, avtomatski in neprostovoljni odziv posameznika na dejavnike iz okolja. Po drugi strani pa t. i. transakcijski model spoprijemanja omenjen pojav razlaga kot zavesten, premišljen in ciljno naravnan specifični odziv posameznika glede na specifične stresorje (Lazarus in Folkman 1984). Z namenom jasne razmejitve med osebnostnimi značilnostmi in spoprijemanjem bomo za namene prispevka spoprijemanje opredelili kot posameznikov zavesten, nameren poskus nadzorovati svoje okolje oz. kot posameznikov zavestni odziv na vplive stresorjev v stresnih situacijah (Compas idr. 2001). 
Spoprijemanje

s stresom (angl. coping)

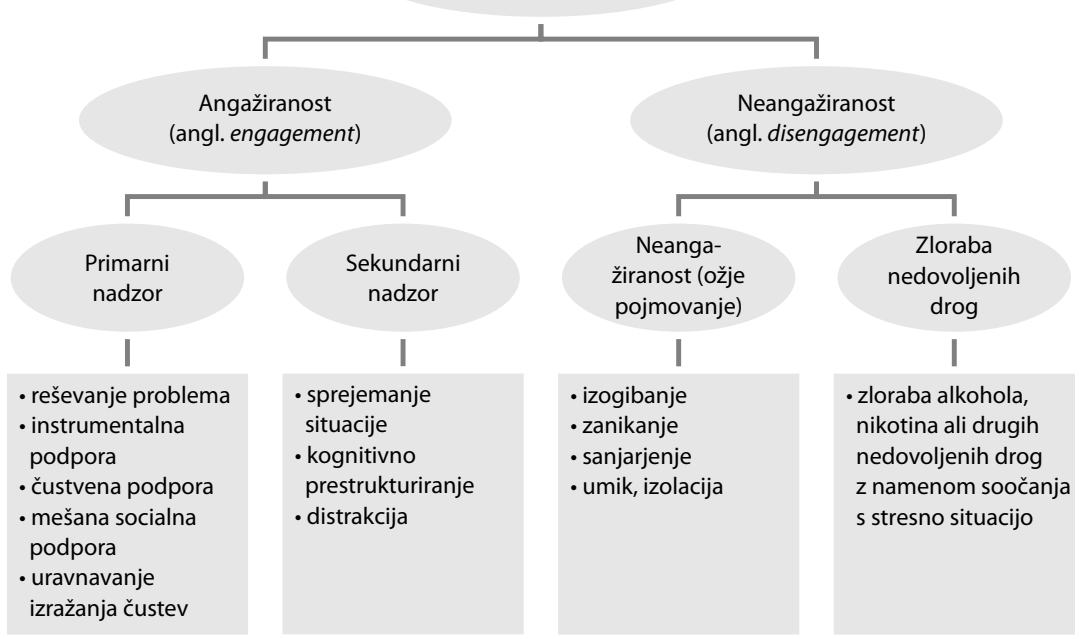

Slika 1 Hierarhična struktura in organizacija strategij spoprijemanja s stresom (povzeto po Connor-Smith in Flachsbart 2007, 1082)

Raziskovanje spoprijemanja s stresom skuša že od druge polovice 20. stoletja posameznikovo spoprijemanje opredeliti s pomočjo različnih modelov, pa vendar metaanaliza več kot 100 modelov in raziskav (Skinner idr. 2003; Connor-Smith in Flachsbart 2007) podpira hierarhično strukturo spoprijemanja s stresom, ki naj bi najbolje utemeljila organizacijo in povezanost rabe posameznih strategij spoprijemanja (slika 1).

Najvišja hierarhično postavljena delitev strategij spoprijemanja se nanaša na posameznikovo aktivnost, natančneje angažirano ali neangažirano spoprijemanje s stresom. Na naslednji stopnji lahko angažirano spoprijemanje s stresnimi situacijami nadalje delimo glede na cilj posameznih strategij spoprijemanja (glej sliko 1):

- primarni nadzor angažiranega spoprijemanja (cilj je aktivno spreminjanje stresorja ali čustev, ki se ob tem porajajo) poteka s pomočjo neposrednega reševanja težave in obvladovanja stresorja s pomočjo načrtovanja, logične analize in implementacije možnih rešitev; iskanja instrumentalne, socialne ali čustvene podpore, torej uporabe različnih virov pomoči pri obvladovanju stresorja; uravnavanja in ustreznega izražanja čustev, ki se kaže kot zmanjšanje izražanja neprijetnih čustev s pomočjo uporabe sprostitvenih tehnik ali modulacije čustvene izraznosti, 
torej konstruktivnega izražanja neprijetnih čustev v primernem času in okolju;

- sekundarni nadzor angažiranega sprejemanja (cilj je povečati prilagajanje posameznika na stresno situacijo), ki se kaže kot sprejemanje situacije kot stanja, ki se ga ne more spremeniti in se skuša z njim živeti; kot kognitivno prestrukturiranje, kar pomeni, da posameznik miselno preoblikuje lastno dojemanje situacije (skuša poiskati pozitivne, realistične plati dogajanja, razmišlja o situaciji kot možnosti za učenje, (osebnostno) rast in razvoj ipd.) ali pa skuša nadzorovati svoje spoprijemanje s pomočjo distrakcije, torej začasnega nadomeščanja spoprijemanja s stresom z neko drugo, prijetnejšo aktivnostjo (pri čemer to ne sme biti poskus umika ali zanikanja težave).

Širše pojmovano neangažirano spoprijemanje pomeni širši nabor odzivov, ki je usmerjeno proč od stresne situacije ali posameznikove reakcije na stresor in se kaže predvsem kot:

- ožje opredeljena neangažiranost, ki zajema poskus posameznikovega izogibanja stresni situaciji ali vsakršnim mislim/čustvom, ki jih stresor sproža; značilno je tudi aktivno zanikanje obstoja težave ali skrivanje čustvenih izrazov sebi/drugim; sanjarjenje ali fantaziranje se kaže kot razmišljanje o tem, da se bo težava čudežno rešila ali izginila, da se bo zgodil (nerealen, neizvedljiv) preobrat ipd.; umik pa se kaže kot namerna samoizolacija, osamljeno preživljanje časa in odločitev, da posameznik ob stresni situaciji misli ali čustev ne deli z nikomer;

- zloraba nedovoljenih drog.

Raziskave (npr. Vollrath 2001; Derryberry, Reed in Pilkenton-Taylor 2003) o povezanosti osebnostnih potez in načinov spoprijemanja kažejo, da lahko pri bolj ekstravertiranih posameznikih pričakujemo več angažiranih načinov spoprijemanja, tako strategij primarnega kot strategij sekundarnega nadzora situacije. Osebe z višjo stopnjo nevroticizima naj bi pogosteje uporabljale neangažirane strategije spoprijemanja, medtem ko naj bi bile pri drugih osebnostnih potezah strategije spoprijemanja manj predvidljive (Connor-Smith in Flachsbart 2007). Tako naj bi posamezniki z bolj izraženo sprejemljivostjo pogosteje uporabljali instrumentalno, čustveno in mešano socialno podporo ter sprejemanje situacije. Osebe $z$ višjo izraženo odprtostjo za izkušnje naj bi pogosteje posegale po angažirani strategiji reševanja težav, sekundarnem načinu angažiranega nadzora situacije ter neangažiranem sanjarjenju in fan- 
taziranju. Osebe z višjo izraženo vestnostjo pa naj bi pogosteje uporabljale angažirano čustveno regulacijo in sekundarne načine angažiranega nadzora stresne situacije.

\section{Problem študije}

Izhajajoč iz predpostavke, da so za uspešen prehod pomembni pripravljenost posameznika, njegovo dobro počutje in pripravljenost sistema (Woodhead in Moss 2007; Ganeson in Ehrich 2009), nas je v raziskavi zanimalo:

- kako so udeleženci raziskave doživljali prehode na različnih stopnjah izobraževanja ( $v$ vrtec, OŠ, SŠ in na fakulteto);

- kako se čustveno-socialne izkušnje doživljanja prehoda na fakulteto povezujejo s pedagoškoprocesnimi elementi študijskega procesa;

- ali lahko govorimo o kontinuiteti čustvenega in socialnega doživljanja med stopnjami izobraževanja, natančneje, ali obstaja povezanost med čustvenim in socialnim doživljanjem prehajanja med stopnjami izobraževanja;

- kako se doživljanje prehodov povezuje z osebnostnimi značilnostmi in s spoprijemanjem s stresom prehoda ter s pedagoškoprocesnimi elementi študijskega procesa.

\section{Metoda}

\section{Vzorec}

$\checkmark$ raziskavi je sodelovalo 117 študentov dodiplomskega študijskega programa (4 - 3,4 \% moških, 81 - 69,2 \% žensk; drugi udeleženci vprašalnika niso izpolnili v celoti) Pedagoške fakultete Univerze na Primorskem (glej preglednico 1). Povprečna starost udeležencev je bila 20,20 let (od 19 do 25 let). Od tega jih je bilo 46 (39,3,6\%) študentov prvega letnika, 27 (23,1\%) študentov drugega letnika in $11(9,4 \%)$ študentov tretjega letnika pedagoških študijskih programov. Povprečna ocena na študiju pa je bila $8,30(S D=0,71$; v razponu od 7,00 do 10,00). Število in strukturni delež udeležencev raziskave po posamezni fakulteti sta zaradi preglednosti prikazana $v$ preglednici 1.

\section{Pripomočki}

$\checkmark$ raziskavi smo uporabili vprašalnik, ki je bil sestavljen iz treh vsebinskih delov: lestvice BFI-10, vprašalnika doživljanja prehodov na čustvenem, socialnem in pedagoškem področju ter vprašalnika spoprijemanja s stresom.

Osebnost po modelu velikih pet (angl. big five inventory). BFI-10 (Rammstedt in John 2007) je krajša oblika originalne lestvice BFI-44, saj le z desetimi po- 
Preglednica 1 Število in delež udeležencev (v odstotkih) po posameznih programih Pedagoške fakultete Univerze na Primorskem

\begin{tabular}{lrr}
\hline Program & Število & Delež \\
\hline Predšolska vzgoja & 35 & 29,9 \\
Razredni pouk & 16 & 13,7 \\
Pedagogika & 22 & 18,8 \\
Socialna pedagogika & 11 & 9,4 \\
Manjkajoči podatek & 33 & 28,3 \\
\hline Skupaj & 117 & 100 \\
\hline
\end{tabular}

stavkami meri velikih pet osebnostnih potez - ekstravertnost, sprejemljivost, vestnost, nevroticizem in odprtost za izkušnje. BFI-10 ima pet podlestvic z dvema postavkama za vsako osebnostno potezo. Udeleženci na posamezne trditve odgovarjajo na petstopenjski Likertovi lestvici (1 - sploh ne drži; 5 popolnoma drži). Ker Cronbachov $\alpha$-koeficient zanesljivosti temelji tudi na dolžini lestvice, krajše verzije lestvic, kot je BFI-10, navadno podcenjujejo zanesljivost merjenih konstruktov. Tako Rammstedtova in John poročata o testretest zanesljivosti omenjenih podlestvic $v$ razponu od o,65 do 0,87, kar kaže na možnosti ustrezne rabe lestvice. Koeficenti zanesljivosti v naši raziskavi so pokazali zadovoljivo stopnjo zanesljivosti zgolj za podlestvice ekstravertnost $(\alpha=0,81)$, nevroticizem $(\alpha=0,73)$ in odprtost za izkušnje $(\alpha=0,53)$. Podlestvici sprejemljivost in vestnost nista izkazovali ustrezne zanesljivosti merjenega konstrukta, zato ju v nadaljnjih analizah nismo uporabili.

Doživljanje prehodov med izobraževalnimi stopnjami. Vprašalnik doživljanja prehodov je vseboval 12 postavk, od tega sta se dve nanašali na doživljanje čustvene in socialne izkušnje vstopanja na vsako nadaljnjo stopnjo izobraževanja (npr. »Zanima nas, kakšna izkušnja je bila za vas vstop v vrtec/OŠ/SŠ/fakulteto na področju doživljanja čustev«), na katere so lahko udeleženci odgovorili na štiristopenjski lestvici (1 - popolnoma neprijetna izkušnja, 2 - neprijetna izkušnja, 3 - prijetna izkušnja, 4 - zelo prijetna izkušnja) ali pa so označili odgovor s 5 - se ne spomnim. Iz analiz smo slednje odgovore izključili. V nadaljevanju pa so udeleženci ob sedmih trditvah na štiristopenjski lestvici (1 - sploh ne drži, 2 - ne drži, 3 - drži, 4 - popolnoma drži; 5 - se ne spomnim) odgovarjali na vprašanje, kaj v odnosu z vzgojiteljem/učiteljem je po njihovem mnenju vplivalo na doživljanja ob vstopu na različne stopnje izobraževanja (npr. »Bil/-a sem dovolj informiran/-a, kaj se bo dogajalo v novem okolju«; »Odrasli v novem okolju so me k učenju spodbujali na ustrezen način«). Lestvica kaže tudi zadovoljivo mero notranje konsistentnosti za vse stopnje izobraževanja (Cronbachova $\alpha$ se giblje od o,75 do 0,93). 
Spoprijemanje s stresom. Vprašalnik spoprijemanja je vseboval sedem trditev, na katere so udeleženci odgovorili na petstopenjski Likertovi lestvici (1 sploh se ne strinjam do 5 - popolnoma se strinjam). Nanašal se je na splošno oceno udeleženca o lastnem delovanju in načinu spoprijemanja s stresom ob prehodih med izobraževalnimi stopnjami (»Na splošno bi rekel, da mi je prehod na [...] pomenil novo priložnost, da pokažem, kaj znam in zmorem." »Na splošno bi rekel, da mi je prehod na [...] pomenil situacijo, iz katere sem pogosto želel zbežati.«). Lestvica kaže na visoko notranjo konsistentnost in zanesljivost $(\alpha=0,80)$. Skupni rezultat na lestvici dobimo kot povprečno vrednost preko vseh postavk.

Za namene raziskave smo zbrali tudi nekatere demografske podatke udeležencev (spol, starost, letnik študija, fakulteta, povprečna ocena v trenutnem študijskem letu).

\section{Postopek zbiranja in obdelave podatkov}

Spletno obliko baterije testov pilotne študije smo aplicirali spomladi 2021 in jo poslali na spletne naslove udeležencev, ki jim je bila ves čas študije zagotovljena anonimnost. Rezultate smo obdelali s pomočjo statističnega paketa SPSS 25.0, s katerim smo analizirali deskriptivne statistike ter preverjali normalnost porazdelitve rezultatov. $V$ nadaljevanju smo za preverjanje povezanosti posameznih konstruktov uporabili Pearsonov $r$-koeficient. Za preverjanje zanesljivosti merjenih konstruktov smo uporabili Cronbachov $\alpha$ koeficient.

\section{Rezultati in interpretacija}

\section{Čustveno in socialno doživljanje ter pedagoškoprocesni elementi na različnih stopnjah izobraževanja}

$\checkmark$ prvem sklopu rezultatov bomo najprej analizirali čustveno in socialno doživljanje prehoda udeležencev med različnimi stopnjami izobraževanja, pri čemer se bomo posebej osredotočili na doživljanje prehoda na fakulteto. Ob tem nas bo zanimalo tudi, kako se je posamezno učno okolje, v katerega so udeleženci vstopali, s pedagoškoprocesnimi elementi nanje odzivalo, ustrezno podprlo njihove potrebe in $\mathrm{s}$ tem olajšalo prehode med stopnjami izobraževanja.

Rezultati kažejo (glej preglednico 2) na visoko do zmerno stopnjo čustvenega doživljanja udeležencev na vseh stopnjah izobraževanja, pri čemer lahko opazimo, da vstop v vrtec, osnovno in srednjo šolo opisujejo kot relativno čustveno intenzivno izkušnjo, vstop na fakulteto pa kot nekoliko manj intenzivno. Doživljanje na socialnem področju, torej ocena udeležencev, $v$ 
Preglednica 2 Opisne statistike intenzivnosti čustvenega in socialnega doživljanja na različnih stopnjah izobraževanja

\begin{tabular}{|c|c|c|c|c|c|c|c|c|c|c|}
\hline \multirow{2}{*}{$\begin{array}{l}\text { Intenzivnost } \\
\text { doživljanja* }\end{array}$} & \multicolumn{2}{|c|}{ Vrtec } & \multicolumn{2}{|c|}{ Osnovna šola } & \multicolumn{2}{|c|}{ Srednja šola } & \multicolumn{4}{|c|}{ Fakulteta } \\
\hline & $N$ & $M(S D)$ & $N$ & $\overline{M(S D)}$ & $N$ & $\overline{M(S D)}$ & $N$ & $M(S D)$ & As. & Spl. \\
\hline Čustveno & 78 & $\begin{array}{c}3,05 \\
(0,82)\end{array}$ & 92 & $\begin{array}{c}3,10 \\
(0,71)\end{array}$ & 89 & $\begin{array}{c}3,16 \\
(0,78)\end{array}$ & 87 & $\begin{array}{c}2,97 \\
(0,72)\end{array}$ & $-0,03$ & $-0,33$ \\
\hline Socialno & 79 & $\begin{array}{c}3,28 \\
(0,72)\end{array}$ & 93 & $\begin{array}{c}3,20 \\
(0,67)\end{array}$ & 89 & $\begin{array}{c}3,36 \\
(0,69)\end{array}$ & 88 & $\begin{array}{c}2,95 \\
(0,77)\end{array}$ & $-0,20$ & $-0,38$ \\
\hline
\end{tabular}

Opombe $N$ - numerus, $M$ - povprečna vrednost, $S D$ - standardni odklon, as. - asimetrija, spl. - sploščenost. * Minimalna in maksimalna vrednost izraženosti vplivov doživljanja za vse stopnje izobraževanja sta bili 1 in 4.

kolikšni meri so se ob vstopu na posamezno stopnjo izobraževanja vključili in povezali z vrstniško skupino, kaže podoben vzorec doživljanja intenzivnosti izkušnje: o najvišji stopnji medsebojne povezanosti poročajo ob vstopu v srednjo šolo, vrtec in osnovno šolo, o najnižji pa ob vstopu na fakulteto. Razloge za slednje lahko najdemo tudi v času zbiranja podatkov, saj je bil vstop na fakulteto na socialnem področju v veliki meri »osiromašen« zaradi razmer v povezavi z epidemijo covida-19. Epidemiološka situacija je namreč zahtevala izvedbo študija na daljavo, kar pomeni, da so bile možnosti za vzpostavljanje socialnih stikov ter vključevanje $v$ vrstniško skupino $v$ živo močno okrnjene. Podobne težave pri vzpostavljanju stikov z vrstniki lahko ugotovimo tudi pri analizi vplivov na doživljanje prehoda na fakulteto (glej preglednico 3), kjer ugotavljamo, da udeleženci predvsem doživljanje prehoda na fakulteto opisujejo kot najmanj intenzivno z vidika vpliva učnega okolja na njihovo delovanje. Podrobna analiza namreč pokaže (glej preglednico 3), da študenti pri prehodu na fakulteto $v$ primerjavi s predhodnimi prehodi med izobraževalnimi stopnjami poročajo o najnižji stopnji informiranosti, čustvene podpore in prejete pozornosti.

Po oceni študentov so dejavnosti in izkušnje na fakulteti pa tudi načini učenja in spodbujanja učenja na fakulteti v primerjavi z drugimi stopnjami izobraževanja najmanj podobni predhodnemu okolju. Zato lahko sklepamo, da ob prehodu na visokošolsko izobraževanje potrebujejo ustrezno in načrtno organizirano podporo $v$ visokošolskem okolju. To odražajo tudi najnižje ocene ustreznosti spodbujanja odraslih k učenju v primerjavi $z$ drugimi stopnjami izobraževanja. Najnižje, $v$ primerjavi z drugimi stopnjami izobraževanja, pa je na visokošolski ravni ocenjeno tudi zanimanje učiteljev za predhodno znanje ter izkušnje študentov in upoštevanje teh izkušenj pri načrtovanju aktualnih dejavnosti na visokošolski ravni, čemur bi bilo z 
Preglednica 3 Opisne statistike pedagoškoprocesnih elementov na doživljanje prehoda na različnih stopnjah izobraževanja

\begin{tabular}{|c|c|c|c|c|c|c|c|c|c|c|}
\hline \multirow{2}{*}{$\begin{array}{l}\text { Pedagoškopro- } \\
\text { cesni elementi* }\end{array}$} & \multicolumn{2}{|c|}{ Vrtec } & \multicolumn{2}{|c|}{ Osnovna šola } & \multicolumn{2}{|c|}{ Srednja šola } & \multicolumn{4}{|c|}{ Fakulteta } \\
\hline & $N$ & $M(S D)$ & $N$ & $M(S D)$ & $N$ & $M(S D)$ & $N$ & $M(S D)$ & As. & Spl. \\
\hline $\begin{array}{l}\text { Bil/-a sem dovolj } \\
\text { informiran/-a, kaj se } \\
\text { bo dogajalo v novem } \\
\text { okolju. }\end{array}$ & 55 & $\begin{array}{c}2,95 \\
(0,71)\end{array}$ & 85 & $\begin{array}{c}3,27 \\
(0,64)\end{array}$ & 91 & $\begin{array}{c}3,19 \\
(0,77)\end{array}$ & 88 & $\begin{array}{c}2,90 \\
(0,80)\end{array}$ & $-0,36$ & $-0,29$ \\
\hline $\begin{array}{l}\text { V novem okolju so se } \\
\text { mi vzgojitelji/učitelji } \\
\text { dovolj posvečali; } \\
\text { deležen/-na sem bila } \\
\text { čustvene podpore in } \\
\text { pozornosti. }\end{array}$ & 86 & $\begin{array}{c}3,29 \\
(0,68)\end{array}$ & 89 & $\begin{array}{c}3,20 \\
(0,65)\end{array}$ & 91 & $\begin{array}{c}3,09 \\
(0,79)\end{array}$ & 88 & $\begin{array}{c}2,83 \\
(0,69)\end{array}$ & $-0,17$ & $-0,09$ \\
\hline $\begin{array}{l}\text { V novem okolju sem z } \\
\text { lahkoto vzpostavil/-a } \\
\text { stik s sovrstniki. }\end{array}$ & 82 & $\begin{array}{c}3,17 \\
(0,68)\end{array}$ & 91 & $\begin{array}{c}3,27 \\
(0,72)\end{array}$ & 91 & $\begin{array}{c}3,22 \\
(0,74)\end{array}$ & 88 & $\begin{array}{c}2,77 \\
(0,87)\end{array}$ & $-0,19$ & $-0,67$ \\
\hline $\begin{array}{l}\text { Dejavnosti in izkuš- } \\
\text { nje v novem okolju so } \\
\text { bile podobne predho- } \\
\text { dnem okolju. }\end{array}$ & 82 & $\begin{array}{c}2,76 \\
(0,78)\end{array}$ & 81 & $\begin{array}{c}2,74 \\
(0,83)\end{array}$ & 91 & $\begin{array}{c}2,58 \\
(0,83)\end{array}$ & 88 & $\begin{array}{c}2,38 \\
(0,81)\end{array}$ & 0,55 & 0,57 \\
\hline $\begin{array}{l}\text { Načini učenja in spod- } \\
\text { bujanja učenja so bili } \\
\text { v novem okolju po- } \\
\text { dobni kot v predho- } \\
\text { dnem okolju. }\end{array}$ & 80 & $\begin{array}{c}2,84 \\
(0,70)\end{array}$ & 80 & $\begin{array}{c}2,55 \\
(0,84)\end{array}$ & 91 & $\begin{array}{c}2,60 \\
(0,79)\end{array}$ & 87 & $\begin{array}{c}2,36 \\
(0,84)\end{array}$ & 0,22 & $-0,43$ \\
\hline $\begin{array}{l}\text { Odrasli v novem oko- } \\
\text { lju so me k učenju } \\
\text { spodbujali na ustre- } \\
\text { zen način. }\end{array}$ & 77 & $\begin{array}{c}3,32 \\
(0,57)\end{array}$ & 90 & $\begin{array}{c}3,28 \\
(0,69)\end{array}$ & 91 & $\begin{array}{c}3,13 \\
(0,75)\end{array}$ & 88 & $\begin{array}{c}3,00 \\
(0,68)\end{array}$ & $-0,68$ & 1,32 \\
\hline $\begin{array}{l}\text { Učitelj je pokazal za- } \\
\text { nimanje za moje do- } \\
\text { takratno znanje in iz- } \\
\text { kušnje ter to upošte- } \\
\text { val pri načrtovanju } \\
\text { aktualnih dejavnosti. }\end{array}$ & 57 & $\begin{array}{c}3,35 \\
(0,64)\end{array}$ & 79 & $\begin{array}{c}3,11 \\
(0,75)\end{array}$ & 90 & $\begin{array}{c}3,09 \\
(0,89)\end{array}$ & 88 & $\begin{array}{c}2,90 \\
(0,86)\end{array}$ & 0,20 & 0,01 \\
\hline
\end{tabular}

Opombe $N$ - numerus, $M$ - povprečna vrednost, $S D$ - standardni odklon, as. - asimetrija, spl. - sploščenost. * Minimalna in maksimalna vrednost izraženosti vplivov doživljanja za vse stopnje izobraževanja sta bili 1 in 4 .

vidika upoštevanja predznanja treba nameniti več pozornosti, predvsem z namenom zagotavljanja smiselnega, diferenciranega in individualiziranega izobraževanja.

V nadaljevanju nas je zanimalo, ali lahko govorimo o kontinuiteti čustve- 
Preglednica 4 Povezanost čustvenega in socialnega doživljanja na posameznih stopnjah izobraževanja

\begin{tabular}{llrrrrrrr}
\hline Stopnja izobraževanja & Doživljanje & 1.b & 2.a & 2.b & $3 . a$ & $3 . b$ & $4 . a$ & $4 . b$ \\
\hline 1. vrtec & a. čustveno & $0,71^{* * *}$ & $0,35^{* *}$ & $0,29^{*}$ & 0,23 & 0,23 & 0,06 & $-0,03$ \\
& b. socialno & & $0,35^{* *}$ & $0,49^{* *}$ & $0,28^{*}$ & $0,29^{*}$ & $-0,03$ & 0,02 \\
\hline 2. osnovna šola & a. čustveno & & & $0,69^{* *}$ & 0,14 & 0,12 & 0,10 & 0,01 \\
& b. socialno & & & & 0,14 & 0,07 & 0,01 & 0,08 \\
\hline 3. srednja šola & a. čustveno & & & & & $0,69^{* *}$ & $0,30^{* *}$ & $0,30^{* *}$ \\
& b. socialno & & & & & & $0,21^{*}$ & $0,21^{*}$ \\
\hline 4. fakulteta & a. čustveno & & & & & & & $0,60^{* *}$ \\
\hline
\end{tabular}

Opombe * ${ }^{*}$ Statistično pomembno na ravni $0,05 .{ }^{* *}$ Statistično pomembno na ravni 0,01 .

nega in socialnega doživljanja med stopnjami izobraževanja, natančneje, ali obstaja povezanost med čustvenim in socialnim doživljanjem prehajanja med stopnjami izobraževanja.

Na osnovi dobljenih rezultatov ugotavljamo dve temeljni značilnosti povezanosti doživljanja med stopnjami izobraževanja (glej preglednico 4). Prvi vzorec povezanosti, ki se pojavlja na vsakem prehodu v izobraževanju, je ta, da se prijetnejše čustveno doživljanje, počutje posameznika v novem okolju visoko pomembno povezuje tudi z njegovim socialnim delovanjem, torej stopnjo, koliko se vključuje v skupino, se znotraj nje čuti sprejet, se povezuje $z$ vrstniki in oblikuje svoje socialne mreže v okviru vrtčevske skupine, šolskega/srednješolskega razreda ali študijskega letnika. O podobnih rezultatih poročajo tudi druge študije (npr. Fredrickson 2004), kjer ugotavljajo, da učenci, ki se $v$ šolskem okolju dobro počutijo, pogosteje stopajo $v$ medosebne odnose, $v$ svoji socialni skupini krepijo občutek pripadnosti in sprejetosti ter poročajo tudi o višjih akademskih dosežkih.

Druga značilnost se kaže kot kontinuiteta čustvenega doživljanja znotraj razvojnopsiholoških obdobij (otroštvo - predšolsko obdobje in osnovna šola; mladostništvo ter prehod $v$ odraslost - vstop v srednjo šolo in na fakulteto) in relativna kontinuiteta socialnega doživljanja prehodov tudi med razvojnopsihološkimi obdobji (med otroštvom in mladostništvom).

Vendar pa se čustveno in socialno doživljanje prehoda na fakulteto povezuje tudi s pedagoškoprocesnimi elementi študijskega procesa (glej preglednico 5). Ugotavljamo namreč lahko, da se pozitivnejše čustvene izkušnje prehoda in večja vključenost $v$ vrstniško socialno skupino pomembno pozitivno povezujejo z vsemi pedagoškoprocesnimi elementi na fakulteti. Študenti namreč poročajo, da višja kot je bila stopnja informiranosti o dogajanju v novem okolju, več pozornosti, čustvene opore ter spodbujanja k učenju na 
Preglednica 5 Povezanost med čustvenim in socialnim doživljanjem ter pedagoškoprocesnimi elementi na fakulteti

\begin{tabular}{|c|c|c|c|c|c|c|c|c|}
\hline & & (1) & (2) & (3) & (4) & (5) & (6) & (7) \\
\hline \multirow[t]{2}{*}{ Doživljanje } & Čustveno & $0,47^{* * *}$ & $0,33^{* * *}$ & $0,49^{* *}$ & $0,23^{*}$ & $0,23^{*}$ & $0,45^{* *}$ & $0,28^{* *}$ \\
\hline & Socialno & $0,40^{* *}$ & $0,50^{* *}$ & $0,74^{* *}$ & $0,31^{* *}$ & 0,15 & $0,46^{* *}$ & $0,47^{* * *}$ \\
\hline \multirow{7}{*}{$\begin{array}{l}\text { Pedagoško- } \\
\text { procesni } \\
\text { elementi }\end{array}$} & $\begin{array}{l}\text { (1) Bil/-a sem dovolj informiran/-a } \\
\text { kaj se bo dogajalo v novem okolju. }\end{array}$ & & $0,44^{* *}$ & $0,41^{* *}$ & $0,36^{* *}$ & $0,31^{* *}$ & $0,47^{* *}$ & $0,27^{*}$ \\
\hline & $\begin{array}{l}\text { (2) V novem okolju so se mi uči- } \\
\text { telji dovolj posvečali; deležen/- } \\
\text { na sem bil/-a čustvene podpore } \\
\text { in pozornosti. }\end{array}$ & & & $0,45^{* *}$ & $0,33^{* *}$ & $0,46^{* *}$ & $0,61^{* *}$ & $0,64^{* *}$ \\
\hline & $\begin{array}{l}\text { (3) V novem okolju sem z lahkoto } \\
\text { vzpostavil/-a stik s sovrstniki. }\end{array}$ & & & & $0,36^{* *}$ & 0,16 & $0,41^{* *}$ & $0,47^{* *}$ \\
\hline & $\begin{array}{l}\text { (4) Dejavnosti in izkušnje na fa- } \\
\text { kulteti so bile podobne dejav- } \\
\text { nostim v srednji šoli. }\end{array}$ & & & & & $0,45^{* *}$ & $0,22^{*}$ & $0,26^{*}$ \\
\hline & $\begin{array}{l}\text { (5) Načini učenja in spodbuja- } \\
\text { nja učenja so bili na fakulteti po- } \\
\text { dobni kot v srednji šoli. }\end{array}$ & & & & & & $0,37^{* *}$ & $0,27^{*}$ \\
\hline & $\begin{array}{l}\text { (6) Odrasli v novem okolju so } \\
\text { me k učenju spodbujali na } \\
\text { ustrezen način. }\end{array}$ & & & & & & & $0,60^{* *}$ \\
\hline & $\begin{array}{l}\text { (7) Učitelj je pokazal zanimanje } \\
\text { za moje dotakratno znanje in iz- } \\
\text { kušnje ter to upošteval pri načr- } \\
\text { tovanju aktualnih dejavnosti. }\end{array}$ & & & & & & & \\
\hline
\end{tabular}

Opombe * Statistično pomembno na ravni $0,05 . *$ Statistično pomembno na ravni 0,01.

ustrezen način so bili deležni, prijetneje in pozitivneje so doživljali prehod na fakulteto. Prav tako menijo, da je bilo doživljanje prehoda na socialnem področju, torej lažje sodelovanje in vzpostavljanje stikov z vrstniki, vključevanje v skupino, skupne dejavnosti ipd., pomembno povezano s tem, da so bili na fakulteti dovolj informirani o delovanju, da so s strani učitelja prejeli dovolj pozornosti in čustvene opore ter da jih je učitelj na ustrezen način spodbujal k učenju in ob tem pokazal zanimanje za njihove predznanje ter izkušnje, ki jih je upošteval pri načrtovanju aktualnih dejavnosti (glej preglednico 5).

Rezultati kažejo, kar ugotavljajo tudi drugi avtorji (Hagenauer in Volet 2014), da so pedagoškoprocesni elementi z ustrezno čustvenospodbudno in učnopodporno interakcijo učiteljev ter podpora celotnega univerzitetnega okolja, $v$ katerega študent vstopa, ključnega pomena za dobro počutje in vključenost študentov na visokošolski ravni izobraževanja. 


\section{Povezanost čustvenega in socialnega doživljanja prehoda, pedagoškoprocesnih elementov, dimenzij osebnosti ter spoprijemanja s prehodom na fakulteto}

$\checkmark$ drugem delu raziskave nas je zanimalo, kateri individualni dejavniki vplivajo na čustveno in socialno doživljanje prehodov in kako. Rezultati kažejo (glej preglednico 6) na zmerno stopnjo spoprijemanja s stresom prehajanja na fakulteto. To pomeni, da so udeleženci na eni strani prehod na fakulteto doživljali kot izziv in novo priložnost za uspeh. Po drugi strani pa so poročali tudi o povečani stopnji tesnobe, strahu, občutka nemoči in občasno o povečani želji zbežati, se umakniti iz stresne situacije. $Z$ vidika analize izraženosti posamezne osebnostne dimenzije lahko ugotavljamo, da se ekstravertnost, nevroticizem in odprtost za izkušnje izražajo zmerno; nekoliko nižje je izražen nevroticizem.

Na osnovi podrobnejše analize povezanosti posameznih individualnih dejavnikov, za katere smo predvidevali, da se povezujejo s prehodom na fakulteto, lahko ugotavljamo dvoje: (i) načini posameznikovega spoprijemanja s stresorji na prehodu na fakulteto so pomembno povezani tako s čustvenim in socialnim vidikom doživljanja kot tudi z večino pedagoškoprocesnih elementov prehoda na fakulteto (glej preglednico 7); (ii) na drugi strani pa se dimenzije osebnosti ne povezujejo pomembno z nobenim izmed merjenih elementov doživljanja prehoda na fakulteto.

V okviru prve ugotovitve lahko torej sklepamo, da je način, kako se študenti soočajo $z$ obremenitvami ob prehodu na fakulteto, pomembno povezan z njihovim čustvenim in socialnim doživljanjem prehajanja na visokošolsko izobraževalno stopnjo. Rezultati namreč kažejo, da študenti $z$ angažiranim spoprijemanjem s stresom prehajanja, torej tisti, ki uporabljajo logično in načrtno pot reševanja problemov, skušajo uravnavati izražanje čustev, kognitivno prestrukturirati situacijo, se spoprijemajo s pomočjo distrakcije ipd. (Connor-Smith in Flachsbart 2007, 1082), poročajo o pomembno višji stopnji

Preglednica 6 Opisne statistike dimenzij osebnosti ter spoprijemanje s stresom na prehodu na fakulteto

\begin{tabular}{|c|c|c|c|c|c|c|c|c|}
\hline & & $N$ & Min & Max & $M$ & $S D$ & As. & Spl. \\
\hline \multicolumn{2}{|c|}{ Spoprijemanje s stresom prehoda } & 86 & 1,86 & 5,00 & 3,58 & 0,72 & $-0,26$ & $-0,46$ \\
\hline \multirow{3}{*}{$\begin{array}{l}\text { Dimenzije } \\
\text { osebnosti }\end{array}$} & Ekstravertnost & 86 & 1,50 & 5,00 & 3,76 & 0,90 & $-0,15$ & $-1,01$ \\
\hline & Nevroticizem & 86 & 2,00 & 4,50 & 3,03 & 0,53 & 0,09 & $-0,15$ \\
\hline & Odprtost za izkušnje & 85 & 1,50 & 5,00 & 3,74 & 0,92 & $-0,33$ & $-0,73$ \\
\hline
\end{tabular}

Opombe $N$ - numerus, $M$ - aritmetična sredina, $S D$ - standardna deviacija, $\mathrm{min} / \mathrm{max}$ - najnižja in najvišja vrednost, as. - asimetričnost, spl. - sploščenost. 
Preglednica 7 Povezanost med doživljanjem prehoda, pedagoškoprocesnimi elementi, dimenzijami osebnosti in spoprijemanjem s stresom prehoda na fakulteto

\begin{tabular}{|c|c|c|c|c|c|}
\hline & & SS & E & $\mathrm{N}$ & $\mathrm{O}$ \\
\hline \multirow[t]{2}{*}{ Doživljanje } & Čustveno & $0,56^{* *}$ & 0,14 & 0,01 & $-0,05$ \\
\hline & Socialno & $0,42^{* *}$ & 0,20 & 0,02 & 0,02 \\
\hline \multirow{10}{*}{$\begin{array}{l}\text { Pedagoško- } \\
\text { procesni } \\
\text { elementi }\end{array}$} & $\begin{array}{l}\text { (1) Bil/-a sem dovolj informiran/-a, kaj se bo dogajalo v } \\
\text { novem okolju }\end{array}$ & $0,46^{* *}$ & $-0,04$ & $-0,03$ & $-0,02$ \\
\hline & $\begin{array}{l}\text { (2) V novem okolju so se mi učitelji dovolj posvečali; } \\
\text { deležen/-na sem bila čustvene podpore in pozornosti }\end{array}$ & $0,42^{* *}$ & 0,06 & 0,03 & 0,03 \\
\hline & $\begin{array}{l}\text { (3) V novem okolju sem z lahkoto vzpostavil/-a stik s so- } \\
\text { vrstniki }\end{array}$ & $0,48^{* *}$ & 0,18 & 0,02 & 0,06 \\
\hline & $\begin{array}{l}\text { (4) Dejavnosti in izkušnje na fakulteti so bile podobne } \\
\text { dejavnostim v srednji šoli }\end{array}$ & 0,21 & $-0,02$ & 0,09 & $-0,03$ \\
\hline & $\begin{array}{l}\text { (5) Načini učenja in spodbujanja učenja so bili na fakul- } \\
\text { teti podobni kot v srednji šoli }\end{array}$ & 0,15 & $-0,03$ & 0,07 & $-0,17$ \\
\hline & $\begin{array}{l}\text { (6) Odrasli v novem okolju so me k učenju spodbujali } \\
\text { na ustrezen način }\end{array}$ & $0,45^{* *}$ & 0,07 & 0,16 & 0,00 \\
\hline & $\begin{array}{l}\text { (7) Učitelj je pokazal zanimanje za moje dotakratno } \\
\text { znanje in izkušnje ter to upošteval pri načrtovanju aktu- } \\
\text { alnih dejavnosti }\end{array}$ & $0,38^{* *}$ & 0,14 & 0,12 & 0,04 \\
\hline & Spoprijemanje s stresom prehoda & & $0,27^{*}$ & 0,02 & 0,15 \\
\hline & Ekstravertnost & & & $-0,04$ & 0,19 \\
\hline & Nevroticizem & & & & $-0,26^{*}$ \\
\hline
\end{tabular}

Opombe SS - spoprijemanje s stresom prehoda, E - ekstravertnost, $\mathrm{N}$ - nevroticizem, $\mathrm{O}$ - odprtost za izkušnje. * Statistično pomembno na ravni $0,05 .{ }^{*}$ Statistično pomembno na ravni 0,01.

doživljanja prijetnih in pozitivnih čustev, lažjemu vključevanju v socialno skupino in posledično uspešnejši prilagoditvi.

Analiza povezanosti osebnostnih potez s čustvenim in socialnim doživljanjem prehoda na fakulteto pa pokaže, da osebnostne dimenzije $v$ našem vzorcu nimajo pomembne povezanosti s tem, kako bo študent doživljal bodisi pedagoškoprocesne elemente bodisi poročal o lastnem čustvenosocialnem doživljanju prehoda.

\section{Sklep}

Posamezniki v otroštvu in mladostništvu prehajajo med različnimi okolji in stopnjami izobraževanja. Najpogosteje obravnavan je bil prehod iz predšolskega obdobja v osnovnošolsko (Arnold idr. 2007). V zadnjem obdobju pa je z namenom zagotavljanja dobrega počutja, vključenosti in študijske uspešnosti predmet zanimanja tudi prehod s srednješolske na visokošolsko raven izobraževanja (Ganeson in Ehrich 2009). V raziskavi, ki smo jo izvedli na vzorcu 
študentov pedagoških študijskih programov Pedagoške fakultete Univerze na Primorskem, nas je zanimalo, kako udeleženci raziskave doživljajo in so doživljali prehode na različnih stopnjah izobraževanja ( $v$ vrtec, OŠ, SŠ in na fakulteto) ter kako se čustveno-socialne izkušnje doživljanja prehoda na fakulteto povezujejo s pedagoškoprocesnimi elementi študijskega procesa. Zanimalo nas je tudi, ali lahko govorimo o kontinuiteti čustvenega in socialnega doživljanja med stopnjami izobraževanja, natančneje, ali obstaja povezanost med čustvenim in socialnim doživljanjem prehajanja med stopnjami izobraževanja, ter kako se doživljanje prehodov povezuje z osebnostnimi značilnostmi, s spoprijemanjem s stresom prehoda ter pedagoškoprocesnimi elementi študijskega procesa.

Študentje visokošolsko raven izobraževanja doživljajo kot okolje, ki se najbolj razlikuje od predhodnega, kar se odraža tudi v drugih ocenah pedagoškoprocesnih elementov, ki so v primerjavi s prehodi na druge stopnje izobraževanja najnižje. Obenem pa ugotavljamo, da se na vseh stopnjah izobraževanja kaže visoka do zmerna stopnja visoka do zmerna stopnja čustvenega in socialnega doživljanja udeležencev, pri čemer so za vstop v vrtec, osnovno in srednjo šolo $v$ primerjavi s fakulteto značilne relativno čustveno intenzivnejše in prijetnejše izkušnje.

Na podlagi rezultatov lahko sklepamo, da se na prehodih in z vstopanjem $\checkmark$ nova izobraževalna okolja pomembno razlikujejo dejavnosti, izkušnje ter načini učenja in spodbujanja učenja $v$ novih okoljih. Relativno visoko pa so študentje ocenjevali ustreznost spodbujanja k učenju v novem okolju, čeprav z vsako višjo stopnjo izobraževanja pada ocena ustreznosti spodbujanja. Ravno tako, v skladu z ocenami študentov, z vsako višjo stopnjo izobraževanja pada tudi zanimanje učiteljev za posameznikove predhodne izkušnje in znanja. Študentje načine podpore ocenujejo kot relativno ustrezne, vendar zaznavamo veliko možnosti za podporo pri vzpostavljanju stikov s kolegi vrstniki ter informiranju o dogajanju v novem okolju in potrebo po čustveni podpori ter pozornosti oz. zanimanju za predhodne izkušnje in znanja. Navedene priložnosti za izboljšave so tudi področja, ki se visoko pozitivno povezujejo s spoprijemanjem študentov s stresom prehoda na fakulteto.

Rezultati potrjujejo dejstvo, da se z vstopanjem na višje stopnje izobraževanja posameznik sooča z neznanim - vsebinami in načini učenja. Ta prehod olajšuje informiranost, vzpostavljanje stikov s sovrstniki, kolegi in ustrezno spodbujanje odraslih pri učenju, kar je tudi značilnost spodbudne interakcije kot ključnega elementa kakovosti tudi na nižjih stopnjah izobraževanja. Za doživljanje prehoda niso ključne posameznikove osebnostne poteze ali podobnost izkušenj ter okolja, v katerega posameznik prehaja, ki se dejansko na 
vsaki stopnji izobraževanja pomembno spremeni. Za boljše spoprijemanje $\mathrm{s}$ prehodom, predvsem $\mathrm{z}$ vidika ustreznega spodbujanja odraslih $\mathrm{k}$ učenju, možnosti navezovanja stikov s kolegi ter ustrezne informiranosti glede študijskih obveznosti in pričakovanj, je namreč ključna podpora - s tem namreč študenti pridobijo pomembno možnost samoregulacije učenja in delovanja.

Spoznanja ponujajo vpogled $v$ doživljanja študentov ob prehodih od vrtca do visokošolske stopnje izobraževanja. Pomembno je predvsem spoznanje, da pri prehodu nista problematična spremembi ter različnost okolij in izkušenj. Za uspešen prehod, torej uspešno spoprijemanje s stresom ob njem, je v skladu z našimi spoznanji ključnega pomena ustreznost podpore - spodbudna čustvena in učnopodporna interakcija učitelja s študenti ter ustrezna informiranost ob prehajanju v nova okolja, kajti, kot kažejo že zgodnje raziskave na tem področju (Astin 1984), pogoste interakacije študentov $s$ fakulteto so bolj povezane z zadovoljstvom študentov kot katera koli druga oblika vključenosti študentov, katera koli značilnost študentov in fakultete. Obenem pa so vzpostavljeni stiki med študenti ključni elementi zagotavljanja mehkega prehoda na visokošolsko raven izobraževanja (Farenga 2018).

\section{Literatura}

Abdullah, M. C., H. Elias, R. Mahyuddin in J. Uli. 2009. »Adjustment amongst First Year Students in a Malaysian University.« European Journal of Social Sciences 8 (3): 496-505.

Alsubaie, M. A. 2015. »Hidden Curriculum as One of Current Issue of Curriculum." Journal of Education and Practice 6 (33): 125-128.

Arnold, C., K. Bartlett, S. Gowani in R. Merali. 2007. »ls Everybody Ready? Readiness, Transition and Continuity: Reflections and Moving Forward.« Working Papers in Early Childhood Development 41, ERIC Clearinghouse.

Astin, A. W. 1984. "Student Involvement: A Developmental Theory for Higher Education. "Journal of College Student Personnel 25 (4): 297-308.

Baik, C., W. Larcombe in A. Brooker. 2019. »How Universities Can Enhance Student Mental Wellbeing: The Student Perspective."Higher Education Research \& Development 38 (4): 674-687.

Beutler, L. E., R. H. Moos in G. Lane. 2003. »Coping, Treatment Planning, and Treatment Outcome: Discussion. « Journal of Clinical Psychology 59 (10): 11511167.

Bronfenbrenner, U. 1979. „Contexts of Child Rearing: Problems and Prospects." American Psychologist 34 (10): 844-850.

Calderon, A. 2018. »Massification of Higher Education.« Power Point presentation, RMIT University, Melbourne, junij.

Compas, B. E., J. K. Connor-Smith, H. Saltzman, A. H. Thomsen in M. E. Wadsworth. 2001. "Coping with Stress during Childhood and Adolescence: Pro- 
gress, Problems, and Potential in Theory and Research."Psychological Bulletin 127 (1): 87-127.

Connor-Smith, J. K., in C. Flachsbart. 2007. »Relations between Personality and Coping: A Meta-Analysis." Journal of Personality and Social Psychology 93 (6): 1080-1107.

Derryberry, D., M. A. Reed in C. Pilkenton-Taylor. 2003. »Temperament and Coping: Advantages of an Individual Differences Perspective.« Development and Psychopathology 15 (4): 1049-1066.

Downes, P. 2019. »Transition as a Displacement from More Fundamental System Concerns: Distinguishing Four Different Meanings of Transition in Education. «ducational Philosophy and Theory 51 (14): 1465-1476.

Dunlop, A. W., in H. Fabian. 2006. Informing Transitions in the Early Years. New York: Open University Press.

Enochs, W. K., in C. B. Roland. 2006. "Social Adjustment to College Freshmen: The Importance of Gender and Living Enviromnent."College/Student Journal 40 (1): 63-72.

Farenga, S. A. 2018. »Early Struggles, Peer Groups and Eventual Success: An Artful Inqiry into Unpacking Transitions into University of Widening Participation Students. « Widening Participation and Lifelong Learning 20 (1): 60-78.

Fredrickson, B. L. 2004. »The Broaden-and-Build Theory of Positive Emotions.« Philosophical Transactions of the Royal Society of London B 359:1367-1378.

Gadzella, B. M., in Carvalho, C. 2006. "Stress Differences among University Female Students."American Journal of Psychological Research 2 (1) 21-27.

Ganeson, K., in C. L. Ehrich. 2009. »Transition into High School: A Phenomenological Study.« Educational Philosophy and Theory 41 (1): 60-78.

Hagenauer, G., in E. S. Volet. 2014. »Teacher-Student Relationship at University: An Important yet Under-Researched Field.« Oxford Review of Education 40 (3): 370-388.

Hendriks, A. A. J., M. Perugini, A. Angleitner, F. Ostendorf, J. A. Johnson, F. De Fruyt, F., M. Hřebíčková, S. Kreitler, T. Murakami, D. Bratko, M. Conner, J. Nagy, A. Rodríguez-Fornells in I. Ruisel. 2003. »The Five-Factor Personality Inventory: Cross-Cultural Generalizability across 13 Countries." European Journal of Personality 17 (5): 347-373.

Lazarus, R. S., in S. Foikman. 1984. Stress, Appraisal and Coping. New York: Springer.

Liddle, C. 2016. »First Peoples: Aboriginal and Torres Strait Islander Participation in Higher Education. «V Student Equity in Australian Higher Education: Twenty-Five Years of a Fair Chance for All, ur. A. Harvey, C. Burnheim in M. Brett, 53-68. Singapore: Springer.

Malaguzzi, L. 1994. "Your Image of the Child: Where Teaching Begins."Child Care Information Exchange 3:52-61.

Markström, A. M., in Simonsson, M. 2017. »Introduction to Preschool: Strategies 
for Managing the Gap between Home and Preschool.« Nordic Journal of Studies in Educational Policy 3 (2): 179-188.

McCloskey, J. D. 2011. »Finally, My Thesis on Academic Procrastination.« Magistrsko delo, University of Texas at Arlington.

McCrae, R. R., P. T. Costa, Jr., F. Ostendorf, A. Angleitner, M. Hřebíčková, M. D. Avia, J. Sanz, M. L. Sánchez-Bernardos, M. E. Kusdil, R. Woodfield, P. R. Saunders in P. B. Smith. 2000. »Nature over Nurture: Temperament, Personality, and Life Span Development." Journal of Personality and Social Psychology 78 (1): 173-186.

Ministrstvo za šolstvo in šport. 1999. Kurikulum za vrtce. Ljubljana: Ministrstvo za šolstvo in šport in Zavod Republike Slovenije za šolstvo.

Ministry of Education, Science and Sport in National Educational Institute Slovenia. 2011. Transitions from Early Childhood Education and Care to Primary Education: OECD Review of Policies and Practices for Transitions from ECEC to Primary Educatio; Country Background Report Slovenia. Ur. N. Požar Matijašič. Ljubljana: Ministry of Education, Science and Sport in National Educational Institute Slovenia.

OECD. 2017. Starting Strong V: Transitions from Early Childhood Education and Care to Primary Education. Pariz: OECD.

Rammstedt, B., in O. John. 2007. »Measuring Personality in One Minute or Less: A 10-Item Short Version of the Big Five Inventory in English and German." Journal of Research in Personality 41 (1): 203-212.

Resman, M. 2008. "Svetovalno delo v vrtcih in šolah."Sodobna pedagogika 59 (2): 6-25.

Skinner, E. A., K. Edge, J. Altman in H. Sherwood. 2003. "Searching for the Structure of Coping: A Review and Critique of Category Systems for Classifying Ways of Coping."Psychological Bulletin 129:216-269.

Steel, P., in J. Ferrari. 2013. "Sex, Education and Procrastination: An Epidemiological Study of Procrastinators' Characteristics from a Global Sample.« European Journal of Personality 27 (1): 51-58.

Univerza na Primorskem. 2016. »Pravilnik o tutorskem sistemu Univerze na Primorskem.«https://www.upr.si/sl/resources/files//univerza/interni-akti/ pravilnik-o-tutorstvu26.10.2016.pdf.

Vollrath, M. 2001. »Personality and Stress. "Scandinavian Journal of Psychology 42 (4): 335-347.

Vonta, T. 1993 Zagotavljanje kontinuitete vzgojnoizobraževalnega dela na prehodu iz vrtca v šolo: elaborat raziskovalne naloge (1. faza). Ljubljana: Pedagoški inštitut.

Vygotsky, S. L. 1978. Mind and Society. Cambridge, MA: Harvard University Press.

Winter, M. S., in F. M. Kelley. 2008. »Forty Years of School Readiness Research: What Have We Learned?« Childhood Education 84 (5): 260-266.

Wintre, M. G., in M. Yaffe. 2000. »First-Year Students' Adjustment to University 
Life as a Function of Relationship with Parents." Journal of Adolescent Research 15 (1): 9-37.

Woodhead, M., in Moss, P., ur. 2007. Early Childhood and Primary Education:Transitions in the Lives of Young Children. Early Childhood in Focus 2. Milton Keynes: Open University.

Zakon o osnovni šoli (ZOsn). 2006. Uradni list Republike Slovenije, št. 81. https:// www.uradni-list.si/1/objava.jsp?sop=2006-01-3535.

Zavod Republike Slovenije za šolstvo. 2008. Programske smernice: svetovalna služba v gimnazijah, nižjih in srednjih poklicnih šolah ter strokovnih šolah in $v$ dijaških domovih. Ljubljana: Zavod Republike Slovenije za šolstvo.

\section{Pedagogical-Psychological Elements of the Transition to Higher Education}

The paper deals with the transitions between different levels of education, with an emphasis on the transition to higher education. We examined how undergraduate students of the Faculty of Education of the University of Primorska experienced transitions at different levels of education, how the continuity of emotional and social experience between levels of education is shown and how emotional and social experiences of transition to the faculty are connected with pedagogical process elements. Results revealed that a more hiher level of well-being of an individual in a new environment, greater social inclusion and used strategies for coping with stress of the transition are significantly associated with the pedagogical process elements. The transition to a higher education environment compared to other levels of education was percieved as the most demanding transition between levels of education. Results confirmed the need for planned organization of processes and activities to support students in the transition to higher education.

Keywords: transition, educational levels, coping, personality, pedagogical process elements, higher education 